

\title{
ANALYSIS OF THE ACQUISITION OF MODEL GROUP BY AB InBev
}

JOSÉ G. VARGAS-HERNÁNDEZ

\begin{abstract}
This paper describes the most important acquisition of the Mexican economy in financial terms, which was concrete in 2013, in which the target was the leading Mexican brewer Grupo Modelo and the buyer the world leader in this sector Ab InBev. The acquisition has brought changes that directly affect the dynamics of the industry in Mexico. This situation favored microbrewers and craft beer segment in the country. The results presented by the company were analyzed to make a comparative analysis of the effects of the transaction on the company, which have been mainly mergers and sales of other economic units belonging to corporate.
\end{abstract}

KEYWORDS: ACQUISITIONS, FDI, GRUPO MODELO, INTERNATIONALIZATION, TAKEOVERS

JEL. F23, G34, L66, M16

\section{RESUMEN}

Este artículo describe la adquisición más importante de la economía mexicana en términos financieros, la cual se concretó en 2013, en la cual el objetivo fue el líder cervecero mexicano Grupo Modelo y el comprador el líder mundial de este sector Ab InBev. La adquisición de Grupo Modelo ha traído cambios que repercuten directamente en la dinámica de la industria en México. Esta situación ha favorecido al micro cervecero y al segmento de la cerveza artesanal en el país. Se analizan los resultados que presentó la empresa para hacer un comparativo y análisis de los efectos de la transacción sobre la empresa. Los cuales han sido, principalmente, otras fusiones y venta de unidades económicas que pertenecían al corporativo. 


\section{INTRODUCTION}

The beer industry in Mexico has an important role because it contributes $2 \%$ of the country's manufacturing industry with about 20,000 million dollars a year, representing $4 \%$ of total tax revenue and generates $0.3 \%$ Gross Domestic Product (INEGI, 2014). The country is the sixth largest producer of beer in the world with 78 million hectoliters (78, 000 million liters) per year. In the ranking of consumption also ranks sixth, with an annual consumption of 62 liters per capita (PROFECO, 2013).

Mexico is one of the leading exporters of beer in the world, reaching 180 countries around the world and generating 2,000 million to the Mexican economy for this item. Mexican beer producers employ 55,000 people, according to the National Chamber of Industry Beer and Malta (Canicerm, 2014). However, the working population is potentially expanding as it is associated with nearly 2 million other jobs; where are outstanding the services which include food preparation; restaurants and recreation amenities.

The beer market in the country has a structure of oligopoly type duopoly because there are two large companies who have more than $98 \%$ of the national market. These two large companies are Grupo Modelo and Grupo Cuauhtemoc-Moctezuma, and both have ceased to be Mexican. In 2010 FEMSA sold to the Dutch company Heineken, the beer division, Cuauhtemoc-Moctezuma, and in 2013 the sale of Grupo Modelo materialize the most important worldwide Belgian-Brazilian brewer Anheuser-Busch InBev (ABInBev).

This article is focused on acquisitions, specifically analyzes the case of Grupo Modelo and the recent acquisition by the company $\mathrm{AB}$ InBev. The terms in which the acquisition is given and the effects it has had on Model Group and the reputation of the goods to consumers are discussed. Changes that have emerged in its corporate governance structure and the strategies commercial level are described. Also, there are analyzed the financial results reported by Grupo Modelo to the Mexican Stock Exchange over fiscal year 2013 to detail those in which acquisition had any effect.

\section{BACKGROUND OF THE PROBLEM}

\section{A. MODEL GROUP}

It is a company dedicated to the development and marketing of beer in Mexico and globally. It lies on the NAICS classification 312120. Founded in 1925 by Braulio Iriarte Goyeneche in Mexico, was sold in 1936 to Pablo Diez Fernandez and kept his Mexican citizenship until 2013 when the acquisition of Anheuser-Busch InBev, the leading brewer in the world, was defined by \$20,100 million USA Dollars. 
Corporate Grupo Modelo has vertical integration since everything is owned by the company. It has a forward and backward integration, i.e., control inputs, production, distribution and sale of beer. Model Group has defined a clear objective: To have a supply chain of excellence and production processes of world class that serve as a platform to develop high quality products at competitive costs with which to satisfy a growing number of consumers.

Grupo Modelo has an installed capacity of 61.5 million hectoliters of beer annually. Currently it has 14 brands, including the one highlighting Corona Extra, which is the Mexican beer sold in the world in 50 markets. It serves 500,000 establishments like grocery stores, supermarkets, restaurants, bars, among others, through 4,500 distribution routes nationwide. Export 7 brands to a total of 180 countries including the United States, Hong Kong, Belgium, New Zealand, Australia, Brazil, Germany, Japan, to name a few.

Group model produces, distributes and sells 14 brands of beer, in different presentations, returnable bottles, non-returnable and can, diversified in different sizes. Besides, through a strategic alliance with Nestlé, produces and distributes in Mexico watermarks bottled Sta Maria, Gerber and Nestlé Pureza Vital. The inputs required for the manufacture of beer are malt, water, hops, yeast and attachments.

\section{B. AB INBEV}

The $\mathrm{Ab}$ InBev group has been formed by a series of mergers and acquisitions that are not detailed in this article. It is considered subject to be treated separately. The group has its beginnings in the Belgian company Interbrew founded in 1987, which in 2004 merged with Brazilian brewer AmBev to form InBev. Then, in 2008 acquired the largest U.S. company, Anheuser-Busch, who had 50\% of the shares of Grupo Modelo and Ab InBev was formed having annual income of 39,758 million dollars.

It has headquarters in Leuven, Belgium and Sao Paulo, Brazil. It is the world's largest brewer, with a U.S. market share of $50 \%$ and $70 \%$ of the European market. Its market share globally is close to $25 \%$. It is the company that produces Budweiser, Stella Artois, Beck's, Staropramen, Leffe and Hoegaarden beers. The company has 120,000 employees in more than 30 countries and with the recent acquisition of the Mexican leader will increase its lead over its main competitors, the British company SABMiller and Heineken Dutch, who occupy the second and third, respectively, in terms of participation in global beer market is concerned. 


\section{DEFINING THE PROBLEM}

In the previous sections of this article it has talked a bit about the importance of the brewing industry in the country as well as companies involved in the acquisition of which is this document. Grupo Modelo has positioned his beer "Corona" not only in the country but has come to conquer international markets, placed fourth as the favorite among consumer preferences globally behind only Bud Light, Budweiser and Heineken according to the BrandZ Top 100 Most Valuable Brands 2013.

Grupo Modelo has a national market share of 55.9\%, a total of 63 million beer drinkers and growing 1 million each year. After the economic crisis of 2008, the brewing industry in Mexico has grown and has a favorable prognosis and it is estimated to increase by $3 \%$ the value of the industry. Model has maintained its leadership in the country and had an internationalization strategy since 1933 when sporadically began exporting to the United States and for 1985 already exported to Japan, Australia, New Zealand and some European countries.

Through an efficient distribution network, a quality product and advertising campaigns and positioning Grupo Modelo get to 180 countries, became the most important globally Mexican beer. Grupo Modelo has achieved that Corona beer dominates the U.S. market as the beer imported beer most sold in the foreign country. The success of Grupo Modelo has never been in doubt, it was one of the most emblematic Mexican brands that was a source of pride for the Mexican consumer, formed a sense of belonging to the brand through its campaign: "In Mexico and the world is Corona beer".

The success and the set of strategies that the company had to pre-acquisition gives place to question the motives that led the owners of this iconic Mexican company to sell their family empire. No doubt this has been the acquisition of greater monetary value for the Mexican economy that have sparked various concerns about the industry itself and the shares of Grupo Modelo. The questions guiding this research are What are the main reasons that led to the former majority owners to sell their profitable business? What have been the effects of the acquisition of Grupo Modelo on the same? What direction will have the beer industry in Mexico? And globally?

\section{A. ASSUMPTION}

The acquisition of Grupo Modelo has brought changes that directly affect the dynamics of the industry in Mexico. This situation favored micro beers manufacturers and craft beer segments in the country. 


\section{CONCEPTUAL THEORETICAL FRAMEWORK}

Based on the theory of internationalization that posits that because the transaction costs to bear as a result of conducting business in imperfect markets, is more efficient (less costly) for firm to use internal structures instead of intermediaries market to serve a foreign market (Beamish and Banks, 1987). The theory suggests several strategies for firms when seeking to enter a foreign market. Pan and Tse (2000) suggest a hierarchical model of entry to other markets, where assets are divided into mode and non-material way. The equity mode is one in which the use of property or capital in the new market entry (Peng, 2010) is involved.

This input mode leads to foreign direct investment (FDI) that is the capital that a foreign firm brings to the economy of another country to invest or acquire a company in the local market. Apart from the benefits of internalization exchange of property assets across international borders, FDI diversified in different places allows a company to take advantage of various locational advantages as a workforce at competitive prices, access to critical resources and to develop new knowledge and skills to improve their international competitiveness (Lu and Beamish, 2001).

An input mode based on equity and FDI are acquisitions that Anand and Delios (2002) defined as a mechanism used to exchange capabilities that are otherwise not possible or redistribute efficiently. As an acquisition, it is the transfer of control of the operations and management of a company (target) to another (purchaser), which makes the first unit in the second (Peng, 2010). The advantages of Ab InBev to make the purchase is that it has full ownership and control of operations, improving its ability to control the global market, no need to add capacity to the company and its strategies are developed faster.

Comprehensive and global strategies are characterized by a high level of globalization of competition in the markets for domestic products that are internationalized and focus on capturing economies of scope and scale (Harzing, 2002). The dominant strategic requirement is efficiency, and as a result, leads to integrate and rationalize its production to produce standardized products in a very cost effective manner.

The acquisition is still very new as it has only been a year since the sale has been concreted and the change of Chairman and CEO of Grupo Modelo, Ab InBev faces the risk that the acquisition will fail due to shocks combined by organizational cultures with clashes of national cultures, poor organization or nationalist concerns against the takeover of foreign companies. For Model Group case must guard the organizational culture it has to, in the transition to Ab InBev's culture, employees have no conflict of adaptation. 
From a market perspective, the issue to take care is protectionism for national brands that may arise in consumers to favor Mexican craft beers which may affect sales of Grupo Modelo to stop being Mexican. To avoid these conflicts will be important decisions to be taken by the new board. The directors seek to develop and maintain a favorable reputation as being active representatives of shareholders, increasing their human capital in the meetings for forming joints and increasing its attractiveness as candidates for board appointments at other firms (Zajac and Westphal, 1996). Also guarding and taking care of their reputation with domestic consumers.

\section{CONTEXTUAL FRAMEWORK}

Anheuser-Busch had 50\% of the shares of Grupo Modelo and after being acquired by In Bev. The current company Ab InBev had in 2008 this participation in the actions of the Mexican company and $43.8 \%$ of the shares entitled to vote. In 2012 it began talking about the intentions to purchase 50\% of the remaining shares of Grupo Modelo brewery giant. Finally, in June 2013 to complete the tender offer (OPA) Grupo Modelo sale was completed by 20,100 million dollars in cash, without conflicts that draw attention but with some resistance from the Mexican shareholders to sell their familiar empire.

The reasons why the Belgian-Brazilian company would acquire Grupo Modelo can be described with statistics and trends of the beer market in key markets in this sector. This company dominates the U.S. and European markets but these markets have presented an unfavorable environment for beer as in the U.S. has decreased the average spending on alcohol consumers from 55\% in 2000 to $48 \%$ in 2011. Also a report by Gallup (2013) poll shows that Americans' preference for beer is $39 \%$ the third time it has fallen below 40\% since 1978 .

The European market has also shown a decrease in beer consumption, in part because consumers are changing the beer table wine and liquor, plus the stagnation of the European economy that does not favor the consumption of this product. This pessimistic outlook for the global brewer took Ab InBev to develop a strategy that would allow it to continue to strengthen as the global leader, saw in Grupo Modelo a chance of favorable conditions for growth presented by this sector in the country.

The beer industry in Mexico has had a growth of 3\% each year. Business Monitor International forecasts a 44\% increase in market sales in Mexico in 2016, resulting in a range of 188 billion pesos for this market. Mexico has culture of beer consumption and as a consumer is the sixth in the world, 53.6\% men and $29.3 \%$ women prefer, according to the 2011 National Survey on Addictions. 
In addition to the upbeat atmosphere of Mexico to the foreign firm, is the fact that this potential market is dominated by Grupo Modelo to have about 56\% of the market share, plus an attractive position both in the domestic market and outside the country, mainly in the United States and countries in Asia such as Hong Kong and Japan. The Mexican leader has always been very attractive by the profit margins and handling is superior to most breweries worldwide, with EBITDA margin (EBITDA) of 30.1\%. These conditions led to $\mathrm{Ab}$ InBev to put their eyes on the Mexican company in its ongoing strategy of M \& As have placed it as number one worldwide.

The reasons for the counterparty have been detailed in the preceding paragraphs, then this is stating the reasons that led to the main owners of Grupo Modelo and board members, Carlos Fernández González, María Asunción Aramburuzabala and Valentin Diez Morodo, decide to sell the most important and profitable brewer in the country, to leave the control of the brewing industry in foreign hands.

Competition among the big global brewers is strong. Grupo Modelo had responded well but its previous administration council decided it was necessary to leave the control to foreign group to increase the profitability of Grupo Modelo and be part of the largest group of global brewer. In 2010 FEMSA decided to sell its beer also a global giant. Modelo felt it necessary to do the same for the firm to grow. However, Grupo Modelo had a growth and its shareholders and directors were focused on it, possibly have overcome the challenges at the world scale but chose not to risk and sell.

Arrogance was also present as the best incentive that had shareholders of Grupo Modelo was the selling price. It is remembered that one of the effects of arrogance is that takeovers pay too much for their goals, even when accepting offers an assessment above the current market price represents an error of assessment (Roll, 1986). Ab InBev paid 20,100 million in cash, representing 15.2 times its value.

Announcing the intention to purchase in 2012, the Department of Justice of United States imposed a claim to oppose, arguing that the acquisition would generate monopolistic practices in the country, because Grupo Modelo had a strategic alliance with the brewer Constellation Brands that formed the Crown Imports. Thanks to this strategic alliance has had a 50\% in the United States which added to the power of Anheuser-Busch could give rise to a monopoly. Ab InBev and Grupo Modelo reached an agreement with U.S. authorities to complete the acquisition.

Model Group was forced to sell its plant in Piedras Negras, Coahuila, the most modernized of the group and where all the beer is produced for export to the United 
States. The transaction also included the perpetual control of the distribution of the Corona brand and model in United States and its stake in the company Crown Imports. The transaction was done with its business partner, Consellation Brand for 2, 900 million dollars. This fact impacted on the final numbers of Grupo Modelo in 2013 as its level of exports decreased by $24.63 \%$, according to the group. This is because the beer sales of the plant no longer belong to the company. Global sales of the company also had fallen in 2013 by $9.1 \%$.

In 2013, prior to the closing of the sale of the Group, Mr. Carlos Fernández González, who had a dual personality of CEO because he was Chairman of the Board and CEO of Grupo Modelo resigned from his positions. On June 4, 2013, Ricardo Tadeu Almeida Cabral became Managing Director of Grupo Modelo and ceased to be a Director General Dual and does not occupy the position of President of the Council.

The Global Strategy Group Model consists of five key points:
A. High growth in international markets
B. Excellence in products and services
C. To promote the standard of excellence in process management
D. Focus on profitability.
E. Integrate and develop human capital in each stage of the implementation of the strategy

In recent years, Model has followed the global strategy which considers the organization as a system. It focuses on improving processes, interaction and alignment with the strategic map and all companies within the group are aligned with the core business of manufacture, distribution and sale of beer and bottled water (Grupo Modelo, 2014). It is a strategy focused on organization, works in the effective dissemination of the same, the proper alignment of resources and the amount of effort towards creating sustainable economic value. No significant changes were made in the core strategy of the company.

The new Board of Proprietary Directors is as follows:
A. Wobeser Hoepfner Claus von Werner (Chair)
B. Carlos Brito Alves
C. Felipe Dutra 
D. Sabine Chalmers

E. Ricardo Tadeu Almeida Cabral De Soares

F. Carlos Fernández González (DG previous dual, Mexican)

G. Luis Fernando de la Pardo Street

H. Jaime Serra Puche

I. José Antonio González Fernández

J. Valentin Diez Morodo (Mexican owner)

K. Maria Asuncion Aramburuzabala Larregui (Mexican owned)

Of the 3 major previous owners of Grupo Modelo, Carlos Fernández González, Valentín Díez Morodo and Maria Asuncion Aramburuzabala Larregui, only the latter has remained as relevant counselor and directive but not with command over the company because she only has $1.72 \%$ of the ordinary shares. Notably, Carlos Fernandez, who was the former director and president and who is also the nephew of the founder of the Group, he does not have now even less than $1 \%$ of the shares of which until 2013 had been the family empire.

Another change made by the new administration began in February 2014 when it announced that it reached an agreement with Circle K by which the company will acquire the business of convenience stores Model Group that operates under the name Extra. The disintegration of the convenience store business allows Grupo Modelo Extra focus on its core business, the manufacture and sale of beer in Mexico and the world. This decision ended with a corporate business that does allow you to focus on the production, Grupo Modelo had been characterized by their full integration into its distribution channel, although it is noteworthy that this acquisition will benefit Circle $\mathrm{K}$ and allow you to advance your competition with OXXO.

$\mathrm{Ab}$ InBev also carried out a merger with the 3 marketing companies that work exclusively for Grupo Modelo, Marketing Modelo, SA de CV, Marcas Modelo, S. of R. L of C.V. and Cervezas Internacionales, SA Ltd., as merged companies which are extincted, so the total assets and liabilities became part of $\mathrm{Ab}$ InBev. This change also represents a change in its marketing strategy which had been successful so far. Also it was carrying out the merger with Diblo and DIFA who were subsidiaries of Grupo Modelo in some production activities of the company. 
The disintegration of the convenience store business Extra allows Grupo Modelo to focus on its core business, the manufacture and sale of beer in Mexico and the world. This decision ended with a corporate business that does allow it to focus on the production, Grupo Modelo had been characterized by its full integration into its distribution channel, although it is noteworthy that this acquisition will benefit Círculo $\mathrm{K}$ and allow it to advance its competition with OXXO.

It can be observed that the sales of Grupo Modelo decreased this year, although by decreasing its operating expenses and increasing the range and price of the product, the difference was less, the utility is greater this due to acquisitions and mergers that kept $\mathrm{Ab}$ InBev year. For better comparisons it is necessary to wait at least another annual report of the company to verify to where it is going the strategy of the new administration.

\section{METHOD}

The method used in this paper is descriptive and analytical, which allows a comparison of the situation of Model Group before and after the acquisition. Because it has only been a year since the sale of the company was completed in June 2013, it is limited simply to compare marketing and financial results in 2012 and 2013. Likewise the most important decisions that have analyzed the new board to try to visualize where are going the $\mathrm{Ab}$ InBev objectives to become the principal of Grupo Modelo.

\section{ANALYSIS RESULTS}

Grupo Modelo is a profitable company, if it was fine to be immersed in a challenging global competition; the former owners had demonstrated that they had the ability to carry Grupo Modelo to success. However, the owners decided not to enter into the global battle and sell their business to the world leader to ensure cost effectiveness. This decision has brought changes to the business model of the company where uncertainty has arisen mainly from the Group's employees that have no assurance on decisions taken by $\mathrm{Ab}$ Inbev in terms of sales, mergers and closures of various economic units of the company.

The larger effect arising after the acquisition was the sale of the plant in Piedras Negras and the rights to its flagship brands in the U.S. market and the fact that these rights were ceded in perpetuity. This suggests that the company will focus on other foreign markets, as is the case in Australia where the beer has increased its market share.

The most important fact of the acquisition has been the loss of the tradition of Mexican beer and subsequent adjustments to positioning campaigns that had been the pride of Mexico. This paves the way for craft beers are positioned in the market as the only $100 \%$ Mexican beers but require large investments to achieve. 
Owner-founders of Grupo Modelo did not take the risk of continuing to face the global market to become a leading company worldwide, but preferred to sell their business when they were in a boom and a favorable financial situation, to avoid facing financial problems, that may have subsequently emerged with the global competition, and be forced to sell at prices below the value of the company. In a financial approach to the shareholders, the acquisition was a good deal, but in the business world has been more visionary to remain in control of the company and face the global competition in which it was already immersed.

Conclusions

Grupo Modelo's sale to a foreign company represents the loss of a symbol as to Mexican brands are concerned. This is because Grupo Modelo had always focused its positioning and advertising campaigns in the pride of being Mexican, carrying various aspects of Mexican culture to countries like Russia, Australia, Japan that have some cultural distance with Mexico. The brand Corona beer created an image and a strong bond with their consumers through the efforts of its managers and employees at all levels; got to be a traditional brand.

The fact that is no longer true Mexican beer can cause disgust that in the local market of craft beer producers could exploit to increase its market share in the country. This situation could represent something favorable to the consumer because competition would achieve to be fairer where the brewing duopoly no longer have control over the prices of beer. Thus, the consumer can acquire other beers. This with the help of the Federal Competition Commission established antitrust regulations.

$\mathrm{Ab}$ InBev will continue to strengthen its position to exploit the domestic market and the Latin market also, which represents a great opportunity in terms of growth, although the situation in the U.S. apparently will remain the same. Due to the sale of rights in perpetuity Corona was forced to make a Constellation. Its market share will remain only from the sales Anheuser-Busch. Grupo Modelo has acquired not benefit greatly in that market. A further question that arises from this millionaire's business what will do the 3 families mostly benefited financially from the sale of Grupo Modelo?

Relevant to the best analysis of the effect on the reputation derived from Grupo Modelo resulting from the sale to foreign group would be developing a market research surveys through a given sample of consumers. It would allow knowing the views of consumers and having better certainty on how the brand has been affected after this decision. This 
study has not been performed due to the limited time that was done the sale. However, it is intended to do it later.

\section{FIGURES AND TABLES}

\section{FIGURES}

Insumos Producción Distribución/Comercialización

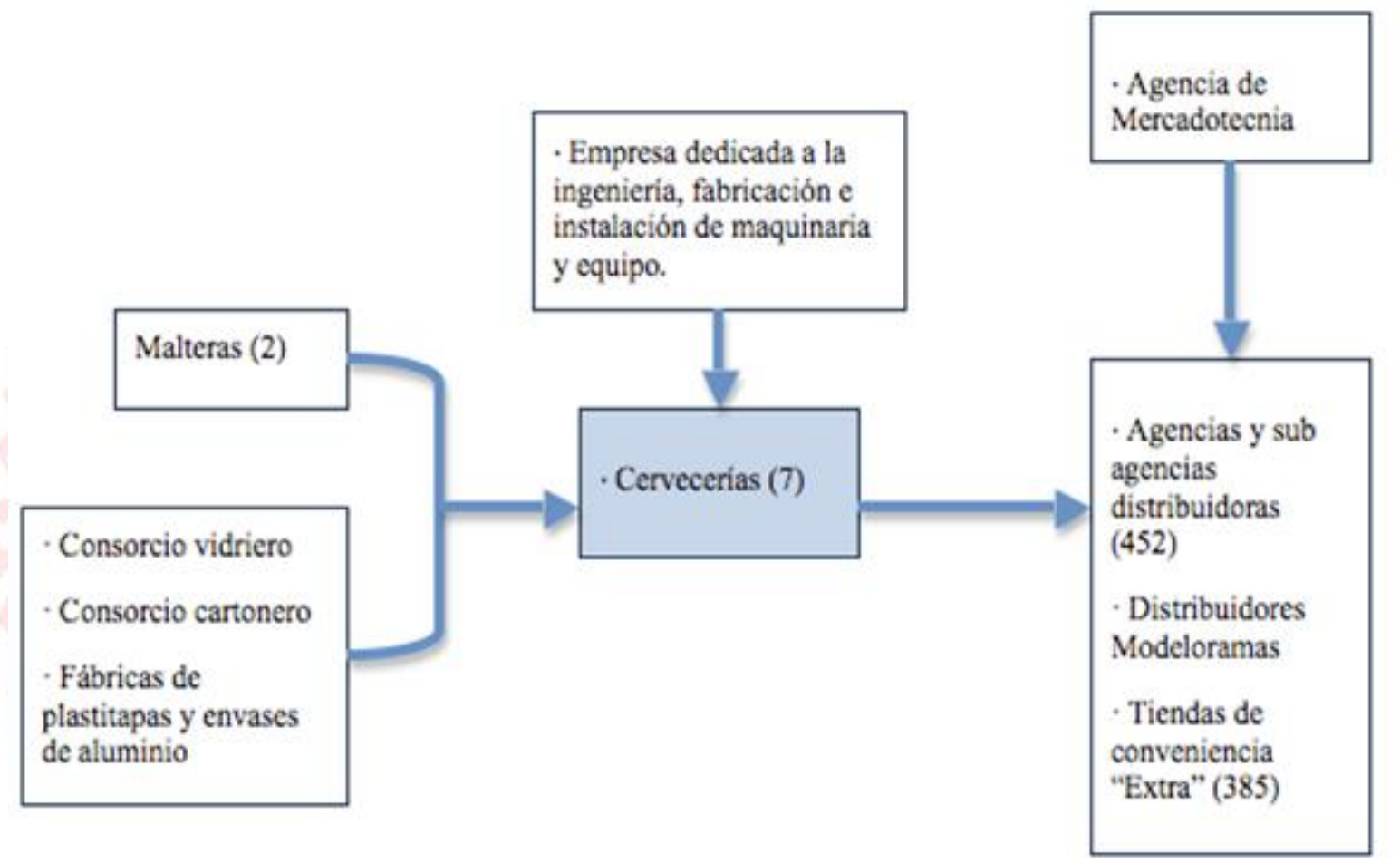

Figure 1: Structure of Model Group. Source: Based on data of Grupo Modelo 
Do you most often drink liquor, wine, or beer?

Based on those who drink alcohol

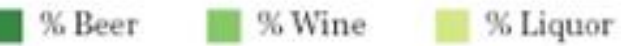

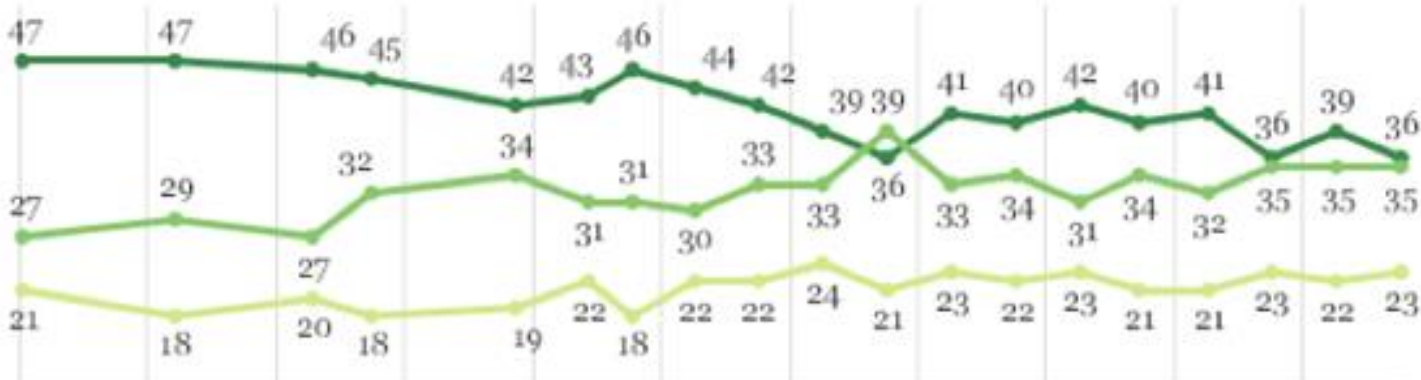

$\begin{array}{lllllllllll}1992 & 1994 & 1996 & 1998 & 2000 & 2002 & 2004 & 2006 & 2008 & 2010 & 2012\end{array}$

Figure 2: Preference for beer in the U.S. market.(Source: Gallup, 2013)

\section{TABLES}

Table 1: Sales of Grupo Modelo (Millions of hectoliters)

\begin{tabular}{|l|l|l|l|l|}
\hline Year & Volume & \% Change & Exports & \% Exports \\
\hline 2006 & 33.98 & & 14.24 & \\
\hline 2007 & 35,61 & 4.80 & 15.94 & 11.94 \\
\hline 2008 & 36.28 & 1.88 & 16.03 & 0.56 \\
\hline 2009 & 37.25 & 2.67 & 15.27 & $-4,74$ \\
\hline 2010 & 36.84 & -1.10 & 15.83 & 3.67 \\
\hline 2011 & 39.09 & 6.11 & 16.9 & 6.76 \\
\hline 2012 & 38.98 & -0.28 & 17.7 & 4.73 \\
\hline 2013 & 38.18 & -020 & 13.34 & -24.63 \\
\hline 2006 & 33.98 & & 14.24 & \\
\hline
\end{tabular}

Source: Own elaboration with data of Grupo Modelo

Table 2: Domestic sales and export, Grupo Modelo.

\begin{tabular}{|l|l|l|l|}
\hline Beer Sales (Millions of Hectoliters) & 2013 & 2012 & 2011 \\
\hline National & 38.18 & 38.98 & 39.09 \\
\hline Exports & 13.34 & 17.70 & 16.90 \\
\hline Total Volume & $\mathbf{5 1 . 5 2}$ & $\mathbf{5 6 . 6 7}$ & $\mathbf{5 5 . 9 9}$ \\
\hline
\end{tabular}

Fuente: Grupo Modelo 
Table 3: Comparison of Model Group sales 2011-2013

\begin{tabular}{|l|l|l|l|}
\hline \multicolumn{1}{|c|}{ Net Sales } & \multicolumn{1}{c|}{2013} & $\%$ & \multicolumn{1}{c|}{2012} \\
\hline National & 63.396 & 71.6 & 59.521 \\
\hline Exports & 25.206 & 28.4 & 39.776 \\
\hline Total Volume & $\mathbf{8 8 . 6 0 2}$ & $\mathbf{1 0 0 . 0}$ & $\mathbf{9 9 . 2 9 7}$ \\
\hline \multirow{3}{*}{ Table 4: Dividend per share in Grupo Modelo. } \\
\cline { 2 - 4 } & \multicolumn{3}{|c|}{ Source: Grupo Model } \\
\cline { 2 - 4 } & 2011 & 2.23 \\
\hline & 2012 & 4.36 \\
\hline & 2013 & 3.57 \\
\hline
\end{tabular}

Source: Grupo Modelo

Table 5: Statement Grupo Modelo 2013

\begin{tabular}{|l|c|c|c|}
\hline \multicolumn{1}{|c|}{ Income Statement } & 2013 & 2012 & 2011 \\
\hline Net sales & 88,603 & 99,297 & 91,006 \\
\hline Gross profit & 48,201 & 52,466 & 47,595 \\
\hline Operating income & 69,280 & 25,106 & 22,027 \\
\hline Income before income taxes & 25,504 & 23,759 & 71.177 \\
\hline Consolidated netincome & 48,510 & 18,915 & 18,285 \\
\hline Net income from participation parent & 48,510 & 12,344 & 11,826 \\
\hline * EBITDA & 73,967 & 29,342 & 25,882 \\
\hline
\end{tabular}

Source: Grupo Modelo

\section{REFERENCES}

[1]. Anand, J. and Delios, A (2002). Absolute and relative resources as determinants of international acquisitions. SMJ, 23: 119-134.

[2]. Beamish, P. and Banks, J (1987). Equity joint ventures and the theory of the multinational enterprise. JIBS, 19: 1-16

[3]. Canicerm, (2014). La cerveza en la economía. Recuperado de http://canicerm.org.mx

[4]. Gallup, (2013). U.S. Drinkers Divide Between Beer and Wine as Favorite, Princeton. Recuperado de http://www.gallup.com/poll/163787/drinkers-dividebeer-wine favorite.aspx 
[5]. González, M (2012). ¿Por qué vende modelo? ¿Por qué compra Ab InBev?, El Economista, México. Recuperado de http://eleconomista.com.mx/cajafuerte/2012/06/27/que-vende-modelo-que-compra-ab-inbev

[6]. Grupo Modelo, (2013). Reporte anual 2013, Recuperado de http://www.gmodelo.mx

[7]. Harzing, A. (2002). Acquisitions versus green-field investments. SMJ, 23: 211227

[8]. INEGI, (2012). Encuesta nacional de adicciones 2011, Aguascalientes.

[9]. INEGI, (2014). Encuesta mensual de la industria manufacturera Enero 2014, Recuperado de http://www.inegi.org.mx

[10]. Lu, J. and Beamish, P (2001). The internationalization and performance of SMEs. SMJ, 22: 565-586.

[11]. Pan, Y. and Tse, D (2000). The hierarchical model of market entry modes, Journal of International Business Studies, 31: 535-554

[12]. Peng, M (2010). Estrategia global, México, Cengage Learning Editores.

[13]. PROFECO, (2013). Comunicado 074, Importante para la economía nacional la industria cervecera, México.

[14]. Roll, R (1986). The hubris hypothesis of corporate takeovers. Journal of Business, 59: 197-216. DOI: 002 1-9398/86/5902-0001

[15]. Zajac, E. and J. Westphal (1996). Director reputation, CEO-board power, and the dynamics of board interlocks. ASQ, 41: 507-529.

$$
- \text { END - }
$$




\section{Y 20 res \\ Xnternational Research Journal}

p-ISSN 2202-2821 e-ISSN 1839-6518 (Australian ISSN Agency)

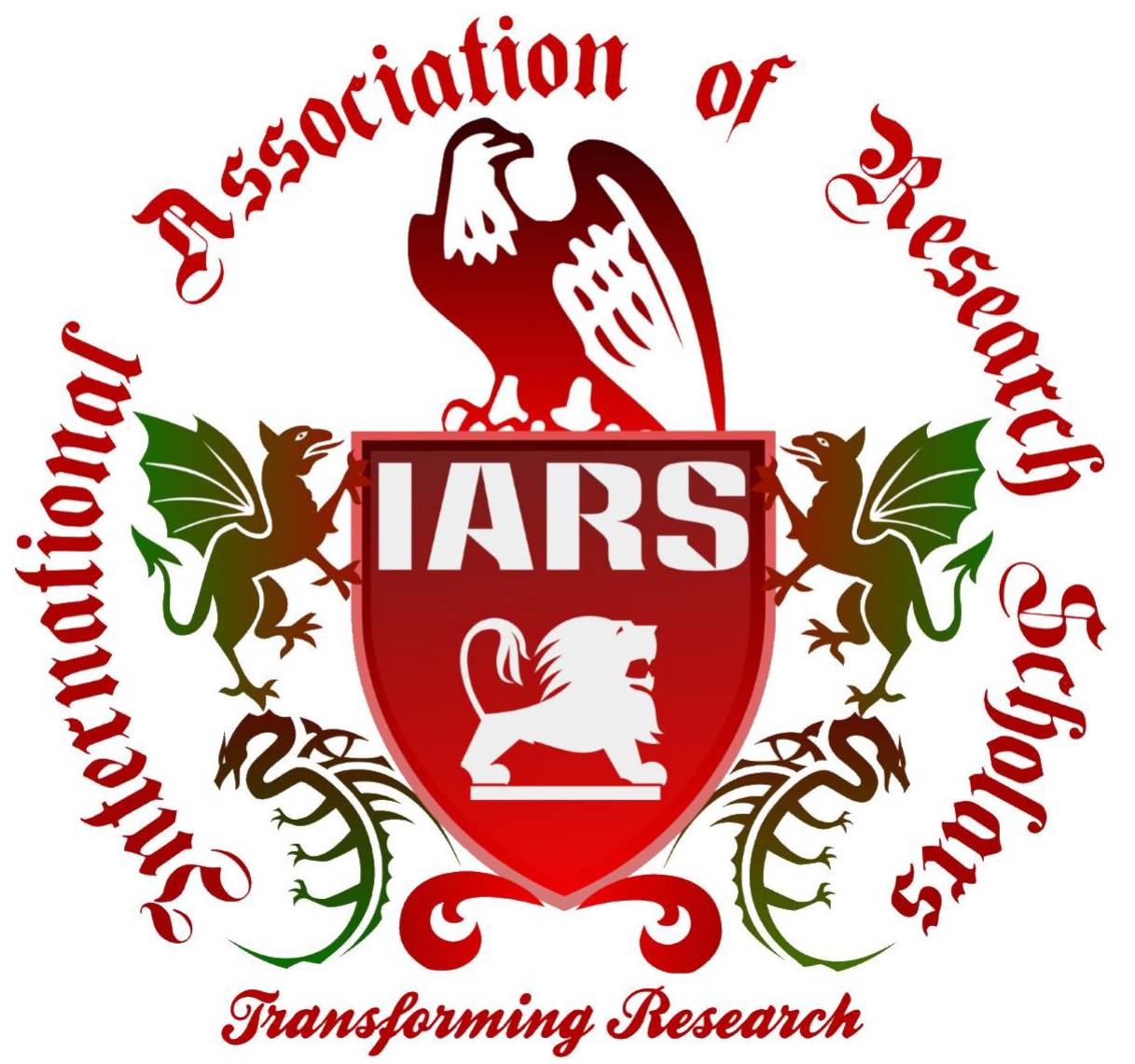

Since 2011 